\title{
Farmers' self-reported value of cooperative membership: evidence from heterogeneous business and organization structures
}

Eeva Alho

\author{
Correspondence: \\ eeva.alho@ptt.fiAQ2 \\ Department of Economics, \\ University of Helsinki and Pellervo \\ Economic Research PTT, Eerikinkatu \\ 28 A, Helsinki 00180, Finland
}

\begin{abstract}
The value of membership of an agricultural producer cooperative to a farmer is universally understood to include market access, improved bargaining power, and reduced transaction costs. As a result of consolidation in agriculture, many farmers in developed countries have found themselves in complex cooperative structures in which market orientation may elevate capital-related membership benefits over the traditional patronage and farming-related benefits. This study utilized the heterogeneity in producer organization structures to examine the significance to farmers of membership in modern agricultural cooperatives. Survey data including 682 Finnish agricultural producers in the livestock sector enabled the subjective value of cooperative membership and the relationship with transaction cost benefits to be analyzed. The effect of vertical integration in cooperatives on the self-reported value of membership benefits was assessed with a sample consisting of members in three types of cooperative organizations: dairy marketing, dairy supply, and meat cooperatives. The findings confirm that a stable market channel is still the most important benefit that producers perceive as deriving from cooperative membership. Multivariate ordered probit analysis indicated that the market channel is equally appreciated by large and small producers, but the reduced uncertainty brought by a cooperative buyer is particularly valuable to farmers who are investing in farm expansion. The survey findings indicate that the more competition for the raw material from producers there is in an area, the greater is the pressure cooperatives may be under to develop their service offering in order to attract members.
\end{abstract}

Keywords: Agricultural cooperatives; Member benefits; Transaction costs; Ordered probit

\section{Background}

Innovations in the forms of producer organizations have emerged over recent decades (van Bekkum and Bijman 2006; Hendrikse and Bijman 2002). The relaxation of restrictions on the residual claims of agricultural cooperatives has been a response to the competitive pressures (Chaddad and Cook 2004). Meat production, in particular, has undergone major structural changes in Europe. The pig meat market is highly integrated, both in production and in the processing industry (Pyykkönen et al. 2012). The consolidation process has led to producer cooperatives adopting hybrid business structures, meaning the transformation of cooperatives towards investor-owned firms (IOF), 
when the cooperatives establish limited liability companies (Bijman et al. 2012). This process is typically motivated by the need to attract risk capital. Cooperatives are owned and controlled by the patrons. Member ownership and control imply that the choice of the organizational form reflects the decisions taken by the members based on their perception of which structure brings them the most value.

Heterogeneity in agricultural producer organizations leads to the question of which factors constitute benefits for the members in modern farmers' cooperatives. Our research strategy was to distinguish preferences at the level of cooperative types without going into farmer-level differences and individual-specific factors that produce differences in preferences. The focus on cooperative types in this paper addresses the topical question of how cooperatives have to change in terms of their member satisfaction and benefit delivery strategies when their cooperative structures change. We utilized a farmer questionnaire to examine the value of agricultural cooperative membership to Finnish milk and meat producers. The survey data, including 682 Finnish agricultural producers in the livestock sector, enabled an analysis of the relationship between the subjective value of cooperative membership and farmer-specific variables. We were also interested in whether the self-reported significance of cooperative benefits to farmers is related to vertically integrated structures. Differences in responses were analyzed with respect to three organization types: marketing, supply, and hybrid cooperatives.

Varying the degree of vertical integration means that a member of either of the first two cooperative types is positioned differently from a member of the other cooperative type. Moreover, moving further from dairy marketing and supply cooperative types to a hybrid reflects the structural shift from traditional cooperative forms towards IOF-like structures. With traditional forms, we refer to the definition of ownership rights in Chaddad and Iliopoulos (2013), in which a traditional cooperative is characterized by residual return rights assigned to member-patrons, ownership is related to patronage, voting rights are non-proportional, and the residual claim is not transferable.

The following literature review discusses the relevant background theories and empirical evidence and builds the research hypotheses. The paper proceeds by presenting the survey data and the methods. The results section presents the survey findings on the perceptions of membership benefits among farmers and the ordered probit analysis of the effect of background variables, after which the final section concludes and discusses the managerial implications.

\section{Background literature and hypotheses}

The existence of cooperatives is traditionally explained as substituting for market failures, serving as a market channel, and in the agricultural sector in particular, bringing countervailing power to farmers (Sykuta and Cook 2001; Hendrikse and Bijman 2002). By organizing market access through a cooperative, farmers are able to benefit from lower costs than they would face by bargaining independently with buyers (Staatz 1987). Transaction cost factors are also present in modern agriculture, which may explain the importance of producer cooperatives in the European food supply chain (Valentinov 2007).

Transaction costs are affected by uncertainty, the frequency of transactions, and asset specificity (Williamson 1989; Ménard 2004). Due to its perishability, a dairy farmer is dependent on the frequent and timely collection of milk from the farm, whereas meat 
is more flexible as a production type (Masten 2000). The obligation of dairy cooperatives to collect all of the milk produced is a valuable membership benefit that economizes on transaction costs and protects specific assets. Consequently, we hypothesized that in our sample, the dairy producers would place greater significance on the cooperative as a stable market channel than the meat producers (hypothesis 1). Large producers may be more dependent on the cooperative as a market channel due to larger asset specificity and potentially large contracting costs if they have to negotiate with several buyers. On the other hand, large producers may have more options due to their better bargaining position and reduced contracting costs for the buyer. In this light, large producers can be hypothesized to be less dependent on a particular cooperative buyer, as Chechin et al. (2013) point out. For small producers, the cooperative offers a safe transaction relationship, and they gain from an improved bargaining position. As the investments in asset specificity and the bargaining power explanations lead to contradicting predictions on the relationship between farm size and the perceived value of a cooperative buyer, we only built a hypothesis on the bargaining power being relatively more valued by small than large producers (hypothesis 2).

Empirical evidence indicates that transaction costs influence farmers' decisions to join and deliver their production to a cooperative. Pascucci et al. (2012) observed that the dependency of farmers on cooperatives increases in relation to the size of their total assets. Their finding suggests that commitment to delivering to a cooperative may strengthen among those farmers who invest a considerable amount in their own production. According to Hernández-Espallardo et al. (2013), satisfying farmer members is crucial to the survival of agricultural marketing cooperatives. They observed the perceived transaction costs to be a more important factor in creating member satisfaction than the producer price.

According to Hansmann (1988), an organizational form emerges that minimizes the transaction costs, and ownership costs explain why ownership rights are assigned to particular patrons. In this framework, the emergence of non-traditional organization models of farmer-owner cooperatives is a result of minimizing of the costs of ownership. Evidence from the field indicates that producer organizations typically aim at finding a model that retains the cooperative form and ideology but enables access to non-member equity capital (van Bekkum and Bijman 2006). Gaining access to growth capital from investors has for many been the decisive factor in departing from the traditional cooperative structure (Chaddad and Iliopoulos 2013). The polar opposite to the traditional cooperative in the typology of Chaddad and Cook (2004) is the transformation into an IOF. The majority of farmer respondents in the survey of Alsemgeest and Smit (2012) perceived profit maximization as the goal currently strived for by agricultural businesses, whereas the provision of competitive services to farmers and improving farm profitability, which were voiced as the main goals, were not in the business focus.

While milk producer cooperatives in Finland represent the traditional cooperative organizational form, i.e., their organization conforms to the cooperative principles of equal treatment of members, equal voting rights, and unallocated capital (Nilsson et al. 2009), large meat cooperatives have adopted vertically integrated hybrid structures in which ownership and control rights are separated from patronage (Pyykkönen et al. 2012). The role of the meat cooperatives is exclusively to exercise ownership and control rights in the stock exchange listed processing and marketing company. We 
expected the members of meat cooperatives to value the price and capital benefits more highly than the members of dairy cooperatives (hypothesis 3 ).

\section{Data and methods}

Data

Surveys were conducted among selected Finnish milk and meat producer cooperatives. The sample was designed to encompass the heterogeneity in producer cooperative structures within Finnish agriculture. Finnish meat producer cooperatives have transformed into holding companies in which the farmers are the owners and members, but they deliver their production to a separate subsidiary corporation. The businesses of processing and marketing further downstream are incorporated in a stock-listed company. As a consequence, our sample of meat producers of the two large Finnish meat cooperatives represented so-called hybrid cooperative structures, which adopt organizational structures similar to those of investor-owned firms. Alternatively, the term IOF-like cooperative could be used. Farmers' organizations have a majority ownership in the firm, but other non-member owners can also invest in the firm's stock in a stock exchange. Altogether, these two meat cooperatives had 3259 members at the end of 2013. The Finnish meat producer population consists of 3500 beef farms, 1540 pig meat farms and 568 poultry farms, i.e., a total of 5608 meat producer farms (Niemi and Ahlstedt, 2013). Therefore, our sample covered a large proportion of the population, and it was also geographically representative, as the two cooperatives operate in the main meat production areas of Finland: cattle in northern and eastern Finland and pigs in southern and western Finland.

Conversely, Finnish dairy cooperatives operate in a traditional agricultural cooperative form, and two variants exist. The market is divided into dairy cooperatives that are part of the Valio Group, in which the role of farmers is to deliver milk and to indirectly exercise ownership in the processing company through their cooperative membership (supply cooperatives). On the other side are dairy cooperatives that are independent of the Valio Group, which take care of the whole chain from milk processing to the marketing of products under their own brand name (marketing cooperatives). Our sample included two large supply cooperatives (i.e., owners of Valio group) and three smaller independent dairy cooperatives, which are referred to as marketing cooperatives. These definitions used in Finland are slightly different from the cooperative types in many other countries. For example in the USA and Canada, supply agricultural cooperatives are those that supply their farmer-members with farm inputs and related services. Here the term supply refers to the supply of farmers' produce to the cooperative. Marketing cooperatives are generally defined as organizations that collect, process, package, and market the farmers' produce.

The total number of dairy producers in Finland was 8373 at the beginning of 2015 (The Central Union of Agricultural Producers and Forest Owners, MTK). The dairy cooperatives included in the sample had a total of 2408 members. Composing the sample of two large dairy supply cooperatives and three marketing cooperatives provided a representative sample in terms of both geography and cooperative type. Comparison of the summary statistics for our sample with the national farmer statistics (Natural Resources Institute of Finland) corroborates the representativeness of the sample in terms of farm and farmer characteristics. 
The questionnaires were delivered by mail in February 2014. The response rates were $16.8 \%$ in the milk producer survey, yielding 406 farmers in the final sample, and $14.3 \%$ in the meat producer survey, which yielded 276 meat farmers. Table 1 presents the farmer characteristics of milk and meat producers separately for members of the dairy supply and marketing cooperatives, and for the meat sectors. Variables that measure farm size (herd size and production volume), distance from the farm to the processing unit, and the number of alternative buyers are indicators of transaction costs. The questionnaire enquired about the intentions to enlarge production or exit farming within the next five years. Dummy variables $(1=$ yes, $0=$ no) were constructed from the responses. Similarly, a dummy indicated whether a farmer had expanded within the previous five-year period.

The Shapiro-Wilk normality test for small samples indicated that only age was normally distributed. Therefore, the analyses proceeded with non-parametric tests. Differences in the variables between the subsamples were tested under the null hypothesis that the distribution of a variable was the same across categories. As the dairy sample

Table 1 Descriptive statistics on dairy and meat farmers

\begin{tabular}{|c|c|c|c|c|c|}
\hline \multirow[t]{4}{*}{ Variable } & \multicolumn{2}{|l|}{ Dairy 1) } & \multicolumn{3}{|l|}{ Meat 2) } \\
\hline & Supply & Marketing & Pig & Cattle & Poultry \\
\hline & Mean & Mean & Mean & Mean & Mean \\
\hline & (st. dev) & (st. dev) & (st. dev) & (st. dev) & (st. dev) \\
\hline \multirow[t]{2}{*}{ Farmer age } & 51 & 49 & 50 & 49 & 50 \\
\hline & $(9.7)$ & $(11.8)$ & $(10.4)$ & $(10.6)$ & $(8.7)$ \\
\hline \multirow[t]{2}{*}{ Field area, hectares } & 61 & 47 & $99^{* * *}$ & $72^{* * *}$ & $84^{* * *}$ \\
\hline & $(52.4)$ & $(30.2)$ & $(67.6)$ & $(61.7)$ & $(47.2)$ \\
\hline \multirow[t]{2}{*}{ Cooperative capital, euro 3) } & 23,800 & 13,960 & $30,480^{* * *}$ & $7,265^{* * *}$ & $44,400^{* * *}$ \\
\hline & $(34,579)$ & $(11,042)$ & $(43,860)$ & $(13,394)$ & $(48,525)$ \\
\hline \multirow[t]{2}{*}{ Alternative buyers } & $1.9^{* *}$ & $2.2^{* *}$ & $3.0^{* * *}$ & $3.0^{* * *}$ & $1.4^{* * *}$ \\
\hline & $(0.91)$ & $(0.81)$ & $(1.44)$ & $(1.51)$ & $(0.67)$ \\
\hline \multirow[t]{2}{*}{ Distance to processing unit } & $70^{* * *}$ & $43^{* * *}$ & $102^{* * *}$ & $139^{* * *}$ & $61^{* * *}$ \\
\hline & $(35.0)$ & $(33.9)$ & $(91.9)$ & $(100.0)$ & $(65.6)$ \\
\hline \multirow[t]{2}{*}{ Herd size 4) } & 33 & 30 & 1241 & 37 & - \\
\hline & $(31.5)$ & $(23.6)$ & $(2826)$ & $(71.2)$ & - \\
\hline Production volume, liters/kg/year 4) & 270.300 & 245,600 & 262,400 & 30,500 & 573,000 \\
\hline Number of respondents & 350 & 56 & 77 & 138 & 26 \\
\hline Female, \% in sample & 24 & 27 & 13 & 15 & 8 \\
\hline Have expanded, \% & 22 & 25 & 17 & 27 & 38 \\
\hline Intention to expand, \% & 20 & 25 & 11 & 22 & 38 \\
\hline Intention to exit, \% & 22 & 14 & 16 & 13 & 0 \\
\hline Region North-East, $\mathrm{N}$ of farmers & 5 & 49 & 2 & 16 & 0 \\
\hline Region West & 261 & 3 & 27 & 58 & 17 \\
\hline
\end{tabular}

1) Mann-Whitney test for difference between supply and marketing in scale variables

2) Kruskall-Wallis test for difference between pig, cattle, and poultry in scale variables

3) Capital suffers from a large number of missing values due to non-responses. Only 122 farmers provided

capital information

4) Herd size and production volume were not tested in meat, as such a comparison is not meaningful due to different

farm structures. Pigs are only reported for farms specializing in piglets, and in cattle for farms that breed calves

${ }^{* * *}(p<0.01),{ }^{* *}(p<0.05),{ }^{*}(p<0.1)$ 
was divided into two categories, the Mann-Whitney test was used, while the KruskallWallis test for three categories was applied to the meat sample.

In the meat sample, all the other background variables differed between the production sectors except for age. Differences between the herd size and production kilograms were not tested, because by definition they differ depending on the livestock. Herd size was not available for poultry. According to the variance tests of two independent samples, the dairy farms in supply and marketing cooperatives had similar characteristics in terms of size, field area, farmer age, and capital, but they differed in terms of alternative buyers and distance. The producers of marketing cooperatives were located closer to the processing unit and they had slightly more alternatives.

The dairy farms had an average herd size of 32 dairy cows, corresponding exactly to the national average (Tike agricultural statistics, 1.5.2014). A herd size of 20-29 cows was the most typical in the sample, which is same as in the Finnish population, as a quarter of dairy farms in Finland are of this size. Dairy farms with more than 40 cows were categorized as large for the present analysis, and 99 dairy farms fell into this category. The pig and cattle subsamples consisted of heterogeneous production. Pig farms can be of three types: pork meat production, raising piglets, or a combination of the two. The size categorization of pig farms took into account the field of specialization: A farm with over 2000 piglets or yearly meat production exceeding the sample average was classified as large. The data on cattle farms possibly included some members of meat cooperatives whose primary production sector was milk, although potential overlaps with the milk sample were screened out.

\section{Methods}

Stated preference questionnaires are suitable research methods for examining perceptions of the benefits that farmers receive from membership of agricultural producer cooperatives and delivering their production to the cooperative. Attitudinal surveys often use Likert scale scoring, in which the extent of agreement is expressed by choosing from the following: 1 = strongly disagree, 2 = disagree, 3 = neither disagree nor agree, $4=$ agree, or $5=$ strongly agree. Dairy and meat farmers used this scale to respond to thirteen statements on how important the mentioned factors were in their membership. The question set was designed to cover a wide range of potential benefits, from the traditional advantages of joining a cooperative, such as access to the market and bargaining power, to benefits originating from structural changes in agriculture to capital-oriented efficient business. The full list of questions is presented in the results section. The questionnaire responses need to be interpreted cautiously, as the responses only reflect the subjective valuation of the respondent's current situation. As such, the self-reported significance of the benefits can be interpreted as satisfaction, or value, scores.

In order to analyze value differences across cooperative types, the Likert scale responses were transformed to three levels, where $3=$ farmer perceives the benefit as significant, 2 = the farmer is indifferent, i.e., perceives neither significant nor insignificant benefits, and $1=$ insignificant benefit perceived by the farmer. The scale data were analyzed using the Mann-Whitney and Kruskall-Wallis tests of independence between the distributions of self-reported values across cooperative types (categories) in $2 \times 3$ and $3 \times 3$ cross-tabulations. Non-parametric tests are suitable when one of the samples is 
drawn from a skewed or peaked distribution (de Winter and Dodou 2010). These statistical tests indicate, whether two independent samples have significant differences. Under the null hypothesis the samples are identical. If the null hypothesis is rejected, the analyzed cooperative types are concluded to differ in terms of the given characteristic.

The relationships between farmer-specific variables that approximated the level of a farmer's transaction costs were analyzed with an ordered probit regression model. Ordered probit is appropriate for statistical analysis of ordinal survey responses, such as the Likert scale, in rating assignments (Greene, 2000). In this study, the estimation method was applied to analyze the effect of farmer characteristics on the likelihood of reporting a certain valuation score for a cooperative benefit. The estimations were conducted using Limdep Nlogit software.

The idea in the ordered probit model is that in addition to $y_{i}$, which is an individual's $i$ (where $i=1, \ldots, n$ ) response to a survey question, and which takes an integer value 1,2 , $3, \ldots, J$, there is a latent index $y_{i}^{*}$, which measures the subjective scale and the propensity to agree with the statement. Once it exceeds a certain threshold, the respondent reports a value of 'significant' and then further 'very significant', along an ordinal scale. The latent index $y_{i}^{*}$ is assumed to depend linearly on the vector of observed characteristics $x_{i}$ that explain an individual's attitude and unobserved factors $\varepsilon_{i}$

$$
y_{i}^{*}=x_{i} \beta+\varepsilon_{i}
$$

What is observed is

$$
\begin{array}{ll}
y_{i}=0 \text { if } & y_{i}{ }^{*} \leq 0 \\
y_{i}=1 \text { if } & 0 \leq y_{i}{ }^{*} \leq \mu_{1} \\
y_{i}=2 \text { if } & \mu_{1} \leq y_{i}{ }^{*} \leq \mu_{2} \\
y_{i}=3 \text { if } & \mu_{2} \leq y_{i}{ }^{*} \leq \mu_{3} \\
y_{i}=4 \text { if } & \mu_{3} \leq y_{i}{ }^{*} \leq \mu_{4}
\end{array}
$$

where $\mu \mathrm{s}$ are unknown parameters to be estimated with $\beta$. They are referred to as the threshold parameters, which are in theory different for all respondents. The estimated threshold parameters are averages over the respondents. This presentation follows the general notation, and is applied here from Greene (2000) and Daykin and Moffatt (2002).

We estimated the ordered probit model for a set of dependent variables, which were the self-reported values (scale 1-5 recoded to $0-4$ for analysis purposes) for the benefit statements and explain the preferred choice with farmer-specific characteristics

$$
\begin{gathered}
y_{i} *=\text { Dairy }_{i} \beta_{1}+\text { Pig }_{i} \beta_{2}+\text { Field area }_{i} \beta_{3}+\text { Expanded }_{i} \beta_{4}+\text { Will expand }_{i} \beta_{5}+\text { Female }_{i} \beta_{6} \\
+ \text { Age }_{i} \beta_{7}+\text { Distance }_{i} \beta_{8}+\text { Dairy-distance }_{i} \beta_{9}+\text { Marketing }_{i} \beta_{10}+\text { Dairy-large }_{i} \beta_{11} \\
+ \text { Pig-large }_{i} \beta_{12}+\text { West }_{i} \beta_{13}+\text { North-East }_{i} \beta_{14}+\varepsilon_{i}
\end{gathered}
$$

where Dairy, Pig, Expanded, Will expand, Female, Marketing, Dairy-large, Pig-large, Region West, and Region North-East are indicator variables taking a value of 1, or zero otherwise, and Field area is measured in hectares, a farmer's Age in years, and Distance represents a farm's distance to the processing unit in tens of kilometers. Dairy-distance is an interaction term that is intended to capture the distance effect specific to the dairy producers. These variables were selected as proxies for transaction costs, because they are common indicators for all producers, irrespective of their production specialization. 
Moreover, they are easy for farmers to report in a questionnaire. Location factors were studied using the distance variable and geographical indicators. Farm size was captured with both the field area and the indicator variable for large producers. Moreover, the intention to expand and recent farm expansion indicated the change in farm size, which was expected to affect the member's relationship with the cooperative.

\section{Results and discussion}

\section{Value of membership benefits}

Farmers considered a stable channel for selling their production as the main benefit provided by cooperative membership. Both milk and meat producers indicated the highest valuations for the statements related to market access (Tables 2 and 3). The cooperative as a stable market channel was significant benefit for $89 \%$ of dairy cooperative members and $83 \%$ of meat cooperative members. Moreover, cooperative membership appears to bring valuable business continuity to producers. Since the dairy cooperative is obliged to collect all the milk produced by its members, the transaction costs from searching for a buyer are reduced. The timing of market access is crucial in milk production due to the perishability of the product and also due to the frequency of milk collection. The benefit of a cooperative buyer with an obligation to collect all of the production was clearly valued by milk producers in this survey.

On the other hand, the role of the meat cooperatives as buyers is somewhat different from dairy cooperatives, since the business is separated from the cooperative in the form of a subsidiary procurement company. However, like the dairy cooperative members, the meat producers in the study highly valued the security of having a destination

Table 2 Benefits of cooperative membership for milk producers

\begin{tabular}{|c|c|c|c|c|}
\hline \multirow[b]{2}{*}{ Statement on the benefits provided by the cooperative } & \multirow[b]{2}{*}{ Average } & \multirow[b]{2}{*}{ Significant } & \multicolumn{2}{|c|}{$\%$ of members } \\
\hline & & & Neutral & Insignificant \\
\hline 1. The cooperative offers a stable market channel. & 4.5 & 89 & 8 & 2 \\
\hline $\begin{array}{l}\text { 2. The cooperative is obliged to collect all of my agricultural } \\
\text { production. }\end{array}$ & 4.6 & 91 & 7 & 2 \\
\hline $\begin{array}{l}\text { 3. As a member of the cooperative, I have better possibilities to } \\
\text { expand my agricultural production. }\end{array}$ & 3.9 & 68 & 23 & 9 \\
\hline 4. The cooperative operates in the nearby region. & 3.9 & 69 & 23 & 8 \\
\hline 5. The cooperative offers good services to the members. & 3.9 & 74 & 21 & 5 \\
\hline 6. The cooperative pays a competitive producer price. & 4.5 & 89 & 9 & 2 \\
\hline 7. I gain other, non-pecuniary benefits from the cooperative. & 3.7 & 60 & 30 & 10 \\
\hline $\begin{array}{l}\text { 8. Producers benefit from a good bargaining position through the } \\
\text { cooperative. }\end{array}$ & 3.8 & 68 & 22 & 10 \\
\hline 9. Cooperative capital is an attractive investment instrument. & 3.6 & 57 & 30 & 13 \\
\hline 10. Membership provides me taxation gains. & 3.4 & 48 & 34 & 18 \\
\hline $\begin{array}{l}\text { 11. Membership provides me control in the governance of the } \\
\text { cooperative. }\end{array}$ & 3.3 & 41 & 38 & 21 \\
\hline $\begin{array}{l}\text { 12. As a member, I have an opportunity to influence business } \\
\text { decisions that promote my own business. }\end{array}$ & 3.4 & 49 & 34 & 17 \\
\hline $\begin{array}{l}\text { 13. As a member, I have an opportunity to carry out work that } \\
\text { supports the community. }\end{array}$ & 3.4 & 44 & 38 & 18 \\
\hline
\end{tabular}

Question: What does cooperative membership mean to you? Indicate on scale of 1 to 5 for each of the statements how important the factors are to your membership. $(5=$ very important ... $1=$ not at all important) 
Table 3 Benefits of cooperative membership for meat producers

\begin{tabular}{|c|c|c|c|c|}
\hline \multirow[b]{2}{*}{ Statement on the benefits provided by the cooperative } & \multirow[b]{2}{*}{ Average } & \multirow[b]{2}{*}{ Significant } & \multicolumn{2}{|c|}{$\%$ of members } \\
\hline & & & Neutral & Insignificant \\
\hline 1. The cooperative offers a stable market channel. & 4.2 & 83 & 12 & 5 \\
\hline 2. Membership secures the marketing of all of my production. ${ }^{a}$ & 4.1 & 78 & 15 & 7 \\
\hline $\begin{array}{l}\text { 3. As a member of the cooperative, I have better possibilities to } \\
\text { expand my agricultural production. }\end{array}$ & 3.4 & 46 & 38 & 16 \\
\hline 4. The cooperative operates in the nearby region. & 3.4 & 48 & 36 & 16 \\
\hline 5. The cooperative offers good services to the members. & 3.3 & 46 & 37 & 17 \\
\hline 6. The cooperative pays a competitive producer price. & 3.8 & 63 & 22 & 15 \\
\hline 7. I gain other, non-pecuniary benefits from the cooperative. & 3.2 & 42 & 37 & 21 \\
\hline $\begin{array}{l}\text { 8. Producers benefit from a good bargaining position through } \\
\text { the cooperative. }\end{array}$ & 3.3 & 45 & 37 & 19 \\
\hline 9. Cooperative capital is an attractive investment instrument. & 3.5 & 58 & 26 & 16 \\
\hline 10. Membership provides me taxation gains. & 3.4 & 46 & 36 & 18 \\
\hline $\begin{array}{l}\text { 11. Membership provides me control in the governance of the } \\
\text { cooperative. }\end{array}$ & 3.0 & 34 & 35 & 30 \\
\hline $\begin{array}{l}\text { 12. As a member, I have an opportunity to influence business } \\
\text { decisions that promote my own business. }\end{array}$ & 3.2 & 45 & 31 & 25 \\
\hline $\begin{array}{l}\text { 13. As a member, I have an opportunity to carry out work that } \\
\text { supports the community. }\end{array}$ & 3.1 & 37 & 37 & 26 \\
\hline
\end{tabular}

Question: What does cooperative membership mean to you? Indicate on scale of 1 to 5 for each of the statements how important the factors are to your membership. $(5=$ very important $\ldots .1=$ not at all important $)$

${ }^{a}$ The wording of statement 2 in the meat producer version of the survey slightly differs from the milk producer version. The statement is, however, intended to convey the same meaning as close as possible. All other statements are the same

for their production, which was indicated by $78 \%$ of respondents stating this as a significant benefit.

A competitive producer price appeared to be a very significant benefit provided by cooperative membership for milk producers (Table 2). After requesting them to score the individual statements, the respondents were asked in a follow-up question to indicate which of the benefits they considered the most important. Among milk producers, a competitive producer price was the second most often stated benefit after a stable market channel. There was, however, a marked difference between the members of milk supply cooperatives and dairy marketing cooperatives in the perceptions of the price. While a competitive producer price was valued highest by $36 \%$ of supply cooperative members, the corresponding proportion was $25 \%$ in the sample of marketing cooperatives. Difference in the valuations of the producer price as a cooperative benefit can probably be explained by the actual price levels paid by the supply and marketing cooperatives included in the sample. Members of the cooperatives supplying milk to the Valio Group had been able to benefit from producer prices that were also relatively high in international comparison. On the other hand, smaller marketing cooperatives, which take care of the whole dairy processing chain and do not engage in profitable business on international markets in the same scale, had on average paid a lower price for the milk of their producers. The sector-wide price pressures that have strained the profitability of meat production over the past few years may explain the relatively lower value of the producer price as a cooperative benefit among the meat producers compared to the dairy farmers (Table 3). 
The dairy farmers agreed quite unanimously with the statement of benefiting from good services offered by the cooperative. Access to production-related services was appreciated, bringing significant value to membership, as only $5 \%$ of milk producers indicated such access as insignificant. However, the cooperative's services were clearly of secondary importance relative to market access and competitive remuneration, as only three respondents out of the total of 384 dairy farmers highlighted these services as the most important benefit. Variable transaction costs on the farm can potentially be lowered if the cooperative is able to arrange essential services in a cost-efficient way. Meat producers did not perceive significant value being derived from services provided by their cooperative. The result may reflect the fact that, in the case of meat, the services are not offered by the cooperative itself but by an associated subsidiary company. Thus, access to fodder advisory and other meat production-related services is indirectly an outcome of cooperative membership.

The perceived value of cooperative membership was not limited to tangible factors such as market access, the producer price, and business facilitating services, but farmers also reported other non-pecuniary benefits as important. While what are perceived as non-pecuniary benefits is subjective, correlations between statement scorings suggest that these benefits may be related to a better bargaining position through the cooperative. In the responses of dairy farmers, the value of non-pecuniary benefits was correlated with control benefits, participating in decision-making that promotes their own farm business, and the opportunity to carry out influential work in support of the community. Meat producers displayed similar interlinkages between the control and influence benefits. However, the meat producers on average placed less value on these factors in cooperative membership than the milk producers.

\section{Effect of cooperative type}

The differences in the valuations of membership benefits across cooperative types are reported in Table 4. Fisher's exact test was employed to test the independence of membership benefit valuations of the cooperative type. This test indicates whether the members of dairy supply, dairy marketing, and meat cooperatives differently value the stated benefits. The z-test values reported for 'significant' show how the groups differ. Superscripts a, b, and c in Table 5 denote the results of the z-test, which compares the column proportions. If the result of the statistical test is insignificant, the members in one of the cooperative types are interpreted to value the stated benefit as much as the members in the other cooperative types. If the performed test gives a significant result, a benefit is interpreted to be more highly valued by the members in a cooperative type whose score is higher.

Milk suppliers and meat producers exhibited different valuations for the cooperative offering a stable market channel and being the destination for all of their production. These factors were relatively more important to the members of supply cooperatives associated with the Valio Group. On the other hand, the members of smaller independent dairy marketing cooperatives responded to statements 1 and 2 in a similar way to the meat farmers. All groups differed in terms of the subjective value of non-pecuniary benefits and the cooperative operating in the local region. Altogether, $85 \%$ of the farmers in dairy marketing cooperatives perceived the proximity of the cooperative as 
Table 4 Differences in the significance of membership benefits according to the cooperative type

\begin{tabular}{|c|c|c|c|}
\hline \multirow{2}{*}{$\begin{array}{l}\text { Statement on the benefits } \\
\text { The cooperative offers a stable market channel }\end{array}$} & Supply dairy & Marketing dairy & Meat \\
\hline & \multicolumn{3}{|c|}{$\%$ of producers } \\
\hline Significant & $90^{\mathrm{a}}$ & $83^{a, b}$ & $83^{b}$ \\
\hline Neutral & 8 & 13 & 12 \\
\hline Insignificant & 2 & 4 & 5 \\
\hline
\end{tabular}

The cooperative is obliged to collect all of my production 1$)^{* * *}$

$\begin{array}{llll}\text { Significant } & 92^{\mathrm{a}} & 89^{\mathrm{a}, \mathrm{b}} & 78^{\mathrm{b}} \\ \text { Neutral } & 6 & 9 & 15 \\ \text { Insignificant } & 2 & 2 & 7\end{array}$

Better possibilities to expand my agricultural production***

$\begin{array}{llll}\text { Significant } & 68^{\mathrm{a}} & 70^{\mathrm{a}} & 46^{\mathrm{b}} \\ \text { Neutral } & 23 & 25 & 38 \\ \text { Insignificant } & 9 & 6 & 16\end{array}$

The cooperative operates in the nearby region***

$\begin{array}{llll}\text { Significant } & 67^{\mathrm{a}} & 85^{\mathrm{b}} & 48^{\mathrm{c}} \\ \text { Neutral } & 24 & 15 & 36 \\ \text { Insignificant } & 9 & 0 & 16\end{array}$

The cooperative offers good services to the members ${ }^{* * *}$

$\begin{array}{llll}\text { Significant } & 73^{\mathrm{a}} & 78^{\mathrm{a}} & 46^{\mathrm{b}} \\ \text { Neutral } & 21 & 22 & 37 \\ \text { Insignificant } & 6 & 0 & 17\end{array}$

The cooperative pays a competitive producer price ${ }^{* * *}$

Significant
Neutral

Insignificant

enefits from the cooperative *** $^{* *}$

$\begin{array}{llll}\text { Significant } & 58^{\mathrm{a}} & 73^{\mathrm{b}} & 42^{\mathrm{c}} \\ \text { Neutral } & 32 & 20 & 37 \\ \text { Insignificant } & 20 & 7 & 21\end{array}$

Benefit from a good bargaining position through the cooperative***

$\begin{array}{llll}\text { Significant } & 67^{\mathrm{a}} & 70^{\mathrm{a}} & 45^{\mathrm{b}} \\ \text { Neutral } & 23 & 17 & 37 \\ \text { Insignificant } & 9 & 13 & 19\end{array}$

Cooperative capital is an attractive investment instrument

$\begin{array}{llll}\text { Significant } & 57^{\mathrm{a}} & 58^{\mathrm{a}} & 58^{\mathrm{a}} \\ \text { Neutral } & 30 & 31 & 27 \\ \text { Insignificant } & 13 & 11 & 16\end{array}$

Membership provides me taxation gains

$\begin{array}{llll}\text { Significant } & 47^{\mathrm{a}} & 50^{\mathrm{a}} & 46^{\mathrm{a}} \\ \text { Neutral } & 35 & 30 & 37 \\ \text { Insignificant } & 18 & 20 & 18\end{array}$

Control in the governance of the cooperative

$\begin{array}{llll}\text { Significant } & 42^{\mathrm{a}} & 42^{\mathrm{a}} & 35^{\mathrm{a}} \\ \text { Neutral } & 37 & 40 & 35 \\ \text { Insignificant } & 22 & 18 & 31\end{array}$


Table 4 Differences in the significance of membership benefits according to the cooperative type (Continued)

\begin{tabular}{|c|c|c|c|}
\hline \multicolumn{4}{|c|}{ Influence in decisions that promote my own business } \\
\hline Significant & $50^{\mathrm{a}}$ & $49^{a}$ & $45^{\mathrm{a}}$ \\
\hline Neutral & 33 & 35 & 30 \\
\hline Insignificant & 17 & 16 & 25 \\
\hline \multicolumn{4}{|c|}{ Opportunity to carry out work that supports the community } \\
\hline Significant & $44^{\mathrm{a}}$ & $42^{\mathrm{a}}$ & $37^{a}$ \\
\hline Neutral & 37 & 44 & 37 \\
\hline Insignificant & 19 & 15 & 26 \\
\hline
\end{tabular}

Membership secures the marketing of all of my production. Superscripts $a$, b, and c denote the results of the z-test, which compares the column proportions. Different letters indicate differences and the level of significance is tested with Fisher exact test. Fisher's exact test ${ }^{* * *}(p<0.01),{ }^{* *}(p<0.05),{ }^{*}(p<0.1)$

significant, while none of them stated it as insignificant. This finding may reflect affective regionalism and a strong sense of community. Dairy producers may feel loyal to their local cooperative, which could possibly explain their decision to join the marketing cooperative and, subsequently, their high valuation of proximity. On the other hand, less than half of the meat producers reported the proximity of the cooperative as beneficial to them. This may be a result of the higher degree of concentration in the meat industry in comparison to the dairy industry. The provision of production-related services appears to have been more important to dairy farmers than to meat farmers. Services were equally appreciated by milk producers in supply and marketing cooperatives.

\section{Size effects}

Similar tests on the impact of farm size are reported in Table 5. Benefits in the form of market access were relatively more significant to large dairy producers than to those classified as small. However, the proportion of farmers reporting 'significant' in statements 1 and 2 was $85 \%$ and $87 \%$ respectively, which underlines the importance of the cooperative as a market channel for all milk producers, irrespective of their size. Due to high asset specificity, large farms may be more dependent on the stability of the milk deliveries and certainty over the buyer for all of their production, a phenomenon for which Pascucci et al. (2012) provided evidence among Italian agricultural producers. Large producers are likely to have more market options than smaller producers because they are relatively more attractive to the buyers, since the contracting costs of the buyer are reduced. In addition due to the economies of scale in doing business with fewer large farms than with many small ones, they can economize on searching and contracting costs when the sole business relationship is with their dairy cooperative, which collects all of their production.

The traditional explanation for farmers forming cooperatives is to gain bargaining power and improve their position in relation to the buyers of their farm production (Valentinov, 2007). We analyzed whether there were systematic differences in the stated value of control and power between small and large producers. In addition, due to the divergence of business practices in dairy and meat sectors, the significance of power factors needed to be analyzed with respect to the specialization of farm production. 
Table 5 Differences in the significance of membership benefits according to producer size

\begin{tabular}{cllll}
\hline Statement on the benefits & Milk small & Milk large & Pig small & Pig large \\
\hline The cooperative offers a stable market channel & \% of producers & & \\
Significant & $87^{\mathrm{a}}$ & $98^{\mathrm{b}}$ & $85^{\mathrm{a}}$ & $76^{\mathrm{a}}$ \\
Chi-squared & $9.86^{* * *}$ & & 1.03
\end{tabular}

The cooperative is obliged to collect all of my production 1)

$\begin{array}{lllll}\text { Significant } & 89^{\mathrm{a}} & 99^{\mathrm{b}} & 81^{\mathrm{a}} & 88^{\mathrm{a}} \\ \text { Chi-squared } & 9.42^{* * *} & & 1.40 & \end{array}$

Better possibilities to expand my agricultural production

\begin{tabular}{|c|c|c|c|}
\hline Significant & $64^{\mathrm{a}}$ & $82^{b}$ & $52^{a}$ \\
\hline Chi-squared & $10.58^{* * *}$ & & 2.81 \\
\hline
\end{tabular}

The cooperative operates in the nearby region

$\begin{array}{lllll}\text { Significant } & 68^{\mathrm{a}} & 74^{\mathrm{a}} & 46^{\mathrm{a}} & 50^{\mathrm{a}} \\ \text { Chi-squared } & 1.94 & & 1.95 & \end{array}$

The cooperative offers good services to the members

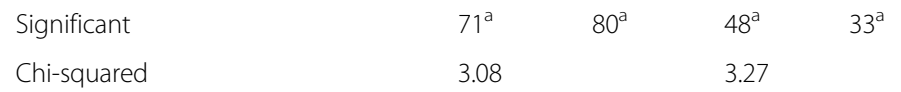

The cooperative pays a competitive producer price

$\begin{array}{lllll}\text { Significant } & 87^{\mathrm{a}} & 94^{\mathrm{a}} & 61^{\mathrm{a}} & 29^{\mathrm{b}} \\ \text { Chi-squared } & 3.17 & & 8.53^{* *} & \end{array}$

I gain other, non-pecuniary benefits from the cooperative

$\begin{array}{lllll}\text { Significant } & 57^{\mathrm{a}} & 69^{\mathrm{b}} & 47^{\mathrm{a}} & 46^{\mathrm{a}} \\ \text { Chi-squared } & 4.71^{*} & & 2.58 & \end{array}$

Benefit from a good bargaining position through the cooperative

$\begin{array}{lllll}\text { Significant } & 65^{\mathrm{a}} & 76^{\mathrm{b}} & 48^{\mathrm{a}} & 29^{\mathrm{a}} \\ \text { Chi-squared } & 4.92^{*} & & 4.99^{*} & \end{array}$

Cooperative capital is an attractive investment instrument

$\begin{array}{lllll}\text { Significant } & 56^{\mathrm{a}} & 60^{\mathrm{a}} & 63^{\mathrm{a}} & 54^{\mathrm{a}} \\ \text { Chi-squared } & 0.52 & & 1.46 & \end{array}$

Membership provides me taxation gains

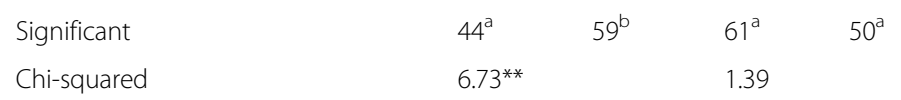

Control in the governance of the cooperative

\begin{tabular}{|c|c|c|c|}
\hline Significant & $39^{a}$ & $45^{\mathrm{a}}$ & $48^{a}$ \\
\hline Chi-squared & 1.20 & & 3.62 \\
\hline
\end{tabular}

Influence in decisions that promote my own business

$\begin{array}{lllll}\text { Significant } & 47^{\mathrm{a}} & 57^{\mathrm{a}} & 52^{\mathrm{a}} & 29^{\mathrm{a}} \\ \text { Chi-squared } & 2.71 & & 4.85^{*} & \end{array}$

Opportunity to carry out work that supports the community

$\begin{array}{lllll}\text { Significant } & 43^{\mathrm{a}} & 47^{\mathrm{a}} & 48^{\mathrm{a}} & 29^{\mathrm{a}} \\ \text { Chi-squared } & 0.52 & & 3.55 & \end{array}$

Membership secures the marketing of all of my production. Superscripts $a$ and $b$ denote the results of the z-test, which compares the column proportions. Different letters indicate differences and the level of significance is tested with Chisquared test. Chi-squared test between large and small separately for milk and pig samples. Responses 'indifferent' and 'insignificant' are omitted for clarity ${ }^{* *}(p<0.01),{ }^{* *}(p<0.05),{ }^{*}(p<0.1)$ 
The meat producer sample included farmers specialized in the pig sector, cattle, or poultry. Size effects could only be analyzed meaningfully with the sample of pig farmers. The dataset on cattle producers was subject to confounding effects, because it was also likely to include some farmers with dairy cows. Specialization in cattle meat production, or combined dairy and meat production, could not be exclusively identified in the data, and size classification based on the reported yearly meat production (kilograms) was therefore unlikely to capture the true size effect in meat production that we were interested in. The dataset on poultry farmers was small, but included quite a balanced sample of small and large producers.

According to the analysis, the valuation of control was indeed related to the size of the pig farm. Consistently with cooperative theory, farmers categorized as small scale attached higher value to gaining control through cooperative membership, the opportunity to take part in decision-making that facilitates their own business, and influence in the community. In addition, $52 \%$ of small pig farmers perceived that cooperative membership empowers them with influence in decision-making that promotes their farm business, while only $29 \%$ of large pig farmers shared this view. Due to the insufficient sample size, z-test statistics were not significant in the pig data, as the number of observations in each category became small. However, the percentages are indicative of direction. Poultry farmers rated the power and control factors on average as highly as the small pig farmers, but no size effect could be found in the small subsample. The opposite effect of size on the importance of control was found among dairy cooperative members. Those classified as large milk producers provided a higher rating on average for the benefits of bargaining power and control than the small milk producers.

The perception of the cooperative as a power and control mechanism is hypothesized to be related to the market and the organizational structures. This means that farmers may have better bargaining power if they have a number of alternative buyers. The governance structures may also affect the ability of producers to negotiate with the buyer. The majority of dairy producers in the marketing cooperatives reported that the number of alternative buyers operating in their region was two ( $43 \%$ of respondents), while quite a large group of marketing cooperative members even had three alternatives (23\%). Only $11 \%$ of respondents in this group reported one buyer. In contrast, $28 \%$ of the dairy producers in supply cooperatives reported that they had only one buyer, while $26 \%$ had two, and $16 \%$ had three.

The presence of more alternatives on average is related to location factors and may explain why the members of marketing cooperatives reported the proximity of the cooperative as being so significant. While they reported having more alternative buyers in the region, the farmers supplying milk to the independent marketing cooperatives more frequently indicated that they had never switched cooperative compared to the farmers supplying milk to the large supply cooperatives of the Valio Group (88 versus $75 \%$ ). The disposition towards switching suggests that those dairy farmers who had the most delivery alternatives did not behave opportunistically and shop around with buyers, but rather remained committed to their local cooperative buyer.

Further analysis of the delivery alternatives provided indications of how farmers benefited from a fragmented market structure with several buyers. The total farmer sample was classified into three groups depending on the reported number of alternative buyers (one, two, or three or more), and the response distributions of membership 
benefits were tested with Fisher's exact test. Three observations related to the transaction cost theory were made. First, farmers who had only one buyer in the region were statistically significantly more likely to value the benefits from access to the market for their whole production through the cooperative than those farmers who had several alternatives. This finding reflects reduced uncertainty. Second, farmers who had more alternative buyers reported on average a higher value for production-related services. A competitive regional market for raw material supply (i.e., more buyers) may provide impetus for buyers to develop their service offering in order to attract and retain members. In such a situation, farmers gain from reduced transaction costs if they obtain the services as a membership benefit more easily and/or more cheaply than they would elsewhere. Third, a similar pattern was observed in the importance of non-pecuniary benefits. As discussed earlier, the statement in the questionnaire did not define in what form the benefit was received, but the result confirms that value from the presence of alternative buyers materializes to farmers as other than price or capital-related benefits.

\section{Regression results}

The multivariate ordered probit (probability) model allowed an examination of the contemporaneous effect of several farmer-specific background variables on the valuation of the membership benefits by farmers. The dependent variables were obtained from the response to the benefit statements $1-13$, as described above. We concentrated on six potential membership benefits that were noted in the previous section to mark differences among farmers and that are theoretically related to transaction costs and the benefits of organizing into farmer cooperatives. The dependent variables were as follows, with the benefit statements they mapped to in parentheses: 1) market channel (statement 1), 2) proximity (statement 3), 3) services (statement 5), 4) producer price (statement 6), 5) bargaining power (statement 8), and 6) control (statement 11). The responses to the seven remaining benefit statements were also estimated in the ordered probit, but are not reported here. Table 6 presents the estimated regression coefficients of the ordered probit models. The interpretation of the coefficients is as probabilities that a farmer characteristic is relevant in explaining the self-reported importance of a benefit.

In model 1, we observed that the market channel opened through cooperative membership was very important to milk producers, but stable market access was also valued by pig farmers. Positive and statistically significant regression coefficients for dummy variables for recently expanded farms and those intending to expand signified the role of the cooperative buyer as a stable transaction partner when the members invested in increasing their production volume. The cooperative market channel was even more important to the farmers who planned to expand in comparison to those who had already invested in enlarging their production. The benefit may arise from reduced transaction uncertainty.

The coefficients for the size indicators were not statistically significant. This result is in line with the earlier notion that cooperative membership provides market access that is unanimously very highly rated by both large and small producers. This holds for both milk and pig sectors, although the coefficient for the pig dummy was negative. The statistically significant coefficient for field, however, suggests that those farms with more 
Table 6 Ordered probit regressions for self-reported value of membership benefits

\begin{tabular}{|c|c|c|c|c|c|c|}
\hline \multirow[t]{2}{*}{ Variable } & (1) & (2) & (3) & (4) & (5) & (6) \\
\hline & Market channel & Proximity & Services & Producer price & Bargaining power & Control \\
\hline \multirow[t]{2}{*}{ Dairy dummy } & $1.242^{* * *}$ & 0.389 & $1.589^{* * *}$ & $1.101^{* * *}$ & $1.049^{* * *}$ & 0.386 \\
\hline & $(0.29)$ & $(0.26)$ & $(0.27)$ & $(0.28)$ & $(0.25)$ & $(0.25)$ \\
\hline \multirow[t]{2}{*}{ Pig dummy } & $0.791^{* * *}$ & 0.096 & 0.430 & 0.437 & $0.509^{*}$ & $0.501^{*}$ \\
\hline & $(0.30)$ & $(0.27)$ & $(0.29)$ & $(0.29)$ & $(0.27)$ & $(0.27)$ \\
\hline \multirow[t]{2}{*}{ Field area } & $-0.105^{* * *}$ & -0.036 & -0.153 & -0.002 & 0.018 & $0.041^{*}$ \\
\hline & $(0.03)$ & $(0.02)$ & $(0.02)$ & $(0.02)$ & $(0.022)$ & $(0.02)$ \\
\hline \multirow[t]{2}{*}{ Buyers } & $0.141^{* * *}$ & $0.112^{* *}$ & $0.087^{*}$ & $0.228^{* * *}$ & $0.143^{* * *}$ & $0.088^{*}$ \\
\hline & $(0.05)$ & $(0.05)$ & $(0.05)$ & $(0.06)$ & $(0.05)$ & $(0.05)$ \\
\hline \multirow[t]{2}{*}{ Expanded dummy } & $0.392^{* *}$ & -0.021 & 0.222 & $0.516^{* * *}$ & $0.401^{* * *}$ & $0.297^{* *}$ \\
\hline & $(0.18)$ & $(0.15)$ & $(0.15)$ & $(0.17)$ & $(0.15)$ & $(0.15)$ \\
\hline \multirow[t]{2}{*}{ Will expand dummy } & $0.515^{* * *}$ & $0.393^{* * *}$ & $0.684^{* * *}$ & $0.482^{* * *}$ & $0.527^{* * *}$ & $0.235^{*}$ \\
\hline & $(0.17)$ & $(0.14)$ & $(0.14)$ & $(0.17)$ & $(0.14)$ & $(0.14)$ \\
\hline \multirow[t]{2}{*}{ Female dummy } & 0.182 & $0.263^{*}$ & $0.355^{* *}$ & $0.303^{*}$ & 0.10 & -0.068 \\
\hline & $(0.18)$ & $(0.15)$ & $(0.15)$ & $(0.18)$ & $(0.15)$ & $(0.14)$ \\
\hline \multirow[t]{2}{*}{ Age } & $0.205^{* * *}$ & $0.022^{* * *}$ & $0.020^{* * *}$ & $0.010^{* *}$ & $0.013^{* * *}$ & $0.015^{* * *}$ \\
\hline & $(0.004)$ & $(0.004)$ & $(0.004)$ & $(0.004)$ & $(0.004)$ & $(0.004)$ \\
\hline \multirow[t]{2}{*}{ Distance, 10 km } & 0.012 & $-0.022^{*}$ & 0.01 & -0.005 & 0.001 & -0.008 \\
\hline & $(0.13)$ & $(0.013$ & $(0.01)$ & $(0.13)$ & $(0.01)$ & $(0.01)$ \\
\hline \multirow[t]{2}{*}{ Dairy-distance interaction } & -0.021 & 0.010 & -0.03 & 0.020 & -0.01 & 0.017 \\
\hline & $(0.03)$ & $(0.02)$ & $(0.02)$ & $(0.03)$ & $(0.02)$ & $(0.02)$ \\
\hline \multirow[t]{2}{*}{ Marketing dummy } & -0.478 & $0.639^{* *}$ & -0.148 & $-0.541^{*}$ & -0.455 & -0.269 \\
\hline & $(0.33)$ & $(0.30)$ & $(0.30)$ & $(0.33)$ & $(0.30)$ & $(0.29)$ \\
\hline \multirow[t]{2}{*}{ Dairy-large dummy } & 0.188 & 0.018 & $-0.303^{*}$ & 0.082 & -0.233 & -0.075 \\
\hline & $(0.21)$ & $(0.17)$ & $(0.17)$ & $(0.21)$ & $(0.17)$ & $(0.16)$ \\
\hline \multirow[t]{2}{*}{ Pig-large dummy } & -0.554 & -0.218 & $-0.914^{* *}$ & $-1.466^{* * *}$ & $-1.352^{* * *}$ & $-1.011^{* * *}$ \\
\hline & $(0.38)$ & $(0.36)$ & $(0.36)$ & $(0.39)$ & $(0.37)$ & $(0.36)$ \\
\hline \multirow[t]{2}{*}{ Region West } & 0.204 & $0.381^{* * *}$ & $-0.269^{*}$ & 0.188 & 0.211 & -0.011 \\
\hline & $(0.16)$ & $(0.14)$ & $(0.25)$ & $(0.16)$ & $(0.14)$ & $(0.14)$ \\
\hline \multirow[t]{2}{*}{ Region North-East } & 0.033 & 0.268 & -0.103 & 0.319 & $0.493^{*}$ & 0.227 \\
\hline & $(0.30)$ & $(0.27)$ & $(0.27)$ & $(0.30)$ & $(0.27)$ & $(0.26)$ \\
\hline \multicolumn{7}{|l|}{ Threshold parameters } \\
\hline \multirow[t]{2}{*}{$\mu_{1}$} & $0.209^{* * *}$ & $0.598^{* * *}$ & $0.771^{* * *}$ & $0.436^{* * *}$ & $0.721^{* * *}$ & $0.799 * * *$ \\
\hline & $(0.08)$ & $(0.07)$ & $(0.09)$ & $(0.09)$ & $(0.08)$ & $(0.07)$ \\
\hline \multirow[t]{2}{*}{$\mu_{2}$} & $0.774^{* * *}$ & $1.430^{* * *}$ & $1.827^{* * *}$ & $1.156^{* * *}$ & $1.701^{* * *}$ & $1.778^{* * *}$ \\
\hline & $(0.086)$ & $(0.069)$ & $(0.075)$ & $(0.08)$ & $(0.07)$ & $(0.07)$ \\
\hline \multirow[t]{2}{*}{$\mu_{1}$} & $1.868^{* * *}$ & $2.556^{* * *}$ & $3.189^{* * *}$ & 1.993 & $2.756^{* * *}$ & $2.729^{* * *}$ \\
\hline & $(0.10)$ & $(0.08)$ & $(0.09)$ & $(0.09)$ & $(0.08)$ & $(0.09)$ \\
\hline N & 362 & 359 & 361 & 358 & 360 & 360 \\
\hline Log likelihood & -316.84 & -472.78 & -434.55 & -351.90 & -465.70 & -518.19 \\
\hline $\mathrm{Chi}^{2}$ & $42.45^{* * *}$ & $38.16^{* * *}$ & $82.55^{* * *}$ & $84.51^{* * *}$ & $54.50^{* * *}$ & $27.08^{* * *}$ \\
\hline Pseudo $R^{2}$ & 0.0628 & 0.0388 & 0.0867 & 0.1072 & 0.0553 & 0.0254 \\
\hline
\end{tabular}

Dependent variables 1-6 are the Likert scale responses to selected value statements recoded to $0-4$. The table reports the estimated probit coefficients and their standard errors in parentheses. The original statements are presented in Tables 2 and $3 .{ }^{* * *}(p<0.01),{ }^{* *}(p<0.05),{ }^{*}(p<0.1)$ 
hectares were less likely to value the market channel as a benefit than smaller farms when measured in field area. A potential explanation is that the farms that receive more of their income from crop farming are not as dependent on their livestock business, and the value of membership is not therefore as tightly linked to production-related benefits. This explanation receives support from the estimations with control, cooperative capital as an attractive investment, and taxation gains as dependent variables, as the field area obtained a positive and statistically significant coefficient. The farmers who owned a large field area derived capital and control-related value from cooperative membership.

Other explanatory variables that obtained statistically significant coefficients in predicting the significance of the market channel were the number of buyers and farmer age. Age appeared to explain the response in all models and was always positive, which suggests that older farmers may be more satisfied with the cooperative relationship. The probability of agreeing with the statement that the cooperative provides benefits as a stable market channel increased with the number of alternative buyers operating in the region. However, running the same regression with statement 2 as a dependent variable (not reported) yielded an insignificant effect of buyer alternatives on the subjective value of the cooperative buying/marketing all of the production. This result is unsurprising, as when the cooperative is the destination for all of the farm production, the presence of more alternatives does not bring added value to cooperative membership.

The estimated marginal effects (Appendix) reveal how a discrete change in the farmer characteristics variable from 0 to 1 affects the prediction of a benefit being reported (very significant), holding all other characteristics as constant. Milk producers were 46 percentage points more likely to rate the market channel benefit as very significant in comparison to meat producers. The coefficient for 'Will expand' indicates that those farmers who intended to enlarge their production were 18 percentage points more likely to report the stable market channel through the cooperative as a very significant benefit compared to the farmers not planning to increase their farm size in the near future.

In model 2, a distance effect among members of the supply and marketing dairy cooperatives was observed. The estimated coefficient for the indicator variable for marketing cooperatives exhibited a positive and statistically significant coefficient. The marginal effects show that farmers of independent marketing cooperatives were 23 percentage points more likely to indicate the proximity of the cooperative as a very significant benefit. Recall that independent cooperative members are on average located closer to the processing unit than the members of dairy supply cooperatives. The ordered probit regression coefficient for distance confirms that farmers located further from the processing unit were less likely to value proximity.

The region indicator suggests that the proximity of the cooperative was valued by farmers in western Finland. This is an area characterized by higher social capital in comparison to the rest of the country (KAKS 2004). People in western Finland have in various studies been found more socially active on average and more satisfied in their relationships with other people. Latent attitudinal factors may be reflected in the self-reported values for proximity. Western farmers were 11 percentage points more likely to report this as very significant. Female farmers were also found to value proximity more highly.

Model 3, with the benefits from production-related services as the dependent variable, confirmed the size effect observed in univariate comparisons in the multivariate 
framework. While the estimated coefficient for the milk producer dummy was positive, the negative sign with the dummy variable for large milk producers implies that service benefits were more significant to smaller producers. The same applies to the small pig farmers. Being a large pig farmer reduced the probability of reporting service benefits as very significant by 15 percentage points. Although large producers appeared to be less satisfied with the cooperative services, those farmers who intended to expand production viewed services as valuable membership benefits. Female farmers were 10 percentage points more likely to report services as very significant compared to male farmers. Producers in the western part of Finland were indifferent or slightly negative towards the value of services as benefits. This result may be a confounding effect of the presence of large pig farms in the area.

Producer price divided the farmers most as a membership benefit. It is a variable that clearly reflects the satisfaction of farmers with the current situation, i.e., the level of the currently paid producer price. Differences between dairy and meat farmers therefore not only reflected organizational heterogeneity, but were inevitably affected by global market prices, pricing conditions of cooperatives, and the profitability pressures on farms. The estimated model 4 reveals that milk producers were more satisfied with price benefit from cooperative membership than meat producers, but the result only applied to the members of the large supply cooperatives associated with the Valio Group. The dummy variable for independent marketing cooperatives captured a negative coefficient of -0.541 , which was statistically significant. Marginal effects revealed that members of small dairy cooperatives were 21 percentage points less likely to agree strongly with receiving a price benefit from their cooperative. This finding is in line with the actual price difference between the dairy cooperative types, since Valio has on average paid a better producer price to its farmers. The independent marketing cooperatives, on the other hand, have paid somewhat lower producer prices in recent years. Size was not found to be a relevant factor in explaining the attitudes of dairy producers towards price benefits. In a dairy cooperative, the price is the same for all members.

Large pig farmers exhibited strong disagreement over the producer price as a membership benefit. Overall, pig farmers were dissatisfied with the pricing of the cooperative. The marginal effects indicate that large pig farmers were 50 percentage points less likely to consider the producer price as a very significant benefit. Female farmers appeared to find the producer price paid by the cooperative acceptable. The presence of more alternative buyers increased the probability that a farmer would be satisfied with the price. This result suggests that in areas where many buyers operate, an attractive price level may hold, because the buyers compete for producers. It may also reflect the bargaining power of farmers.

The effect of farmer-specific factors on the perception of bargaining power through the cooperative is indicated in model 5 . The number of alternative buyers was positively related to the probability of a farmer valuing bargaining power. The marginal effect is moderate but nonetheless indicates a positive 4 percentage points higher probability of strongly agreeing with bargaining position gains when the number of potential buyers increases by one. The farmers who had enlarged their farm production or intended to do so valued the bargaining power benefit from cooperative membership more highly. A large farm size as such did not contribute to the perception of bargaining power 
benefits among dairy and pig farmers. The indicator variable for farm location shows that cooperative membership was associated with the significance of bargaining power benefits in northern or eastern Finland. Potential explanations may be related to differences in structural factors in agriculture between separate regions of Finland, e.g., the production sector, differences in the organizational structures of the buyers, or the size of farms.

Finally, model 6, with control as the dependent variable, demonstrated the effect of field area and the significance of control opportunities to expanding producers. We were not able to confirm a difference in control benefits between dairy and meat sectors. On the contrary, the dummy for pig farmers received a statistically significant positive coefficient, which indicates that they were likely to value control in the governance of the cooperative more highly. However, pig farmers classified as large were 23 percentage points more likely to report control as an insignificant factor than small and medium sized pig farmers.

\section{Conclusions}

Analysis of a questionnaire completed by 682 Finnish milk and meat producers revealed heterogeneity in the perceived valuation of benefits that farmers receive as members of agricultural producer cooperatives. Membership endows cooperative patron-owners with various benefits, of which some are monetary, such as a competitive producer price, attractive capital investments, or taxation gains. Some benefits are tangible and specific business practices, such as access to services, a contract with the cooperative to deliver all production, or the physical proximity of the business. Cooperative membership also brings abstract and less easily perceivable benefits such as bargaining power and influence in decision making. Producers can verify the tangible member benefits, such as services or capital interest, but they may not be able to measure the value of the bargaining power they gain through cooperative membership. Irrespective of the form, member benefits are assumed to bring utility to farmers through decreased transaction costs.

The foremost finding is that producers value many membership benefits as significant. The finding validates the importance of the cooperative organizational form in modern agriculture. However, marked differences in self-reported values were observed with respect to farmer-specific factors, and also to the type of the cooperative. The comparison of the responses between the three cooperative types provided evidence of differing positions among farmers in the vertical integration of agribusinesses. The degree of vertical integration causes a cooperative's role for a producer to be very different depending whether the membership rights are defined in the organizational context of a traditional marketing cooperative, supply cooperative, or an IOF-like hybrid cooperative.

The dairy marketing cooperatives of this study represented the most traditional type of agricultural cooperative, in which the patron-owners are closely involved in the whole process from the supply of milk to processing and marketing of the end products. Members of dairy supply cooperatives included in the sample have a role of supplying and exercising ownership rights in the cooperative and indirectly in the central group company under whose brand name the products are collectively marketed. Members of the hybrid type of meat cooperatives are most distanced from the end markets. The role of the meat cooperatives is to exercise ownership and control rights in the stock exchange listed processing and marketing company. It is evident that 
heterogeneity in organizational structures is related to the valuation of benefits by farmers and how significant cooperative membership is to them. However, the causation could not be confirmed and is left for future studies. The perceived value of the cooperative to its members may affect their decisions as the owners to choose another organizational structure that better corresponds to their valuations.

The benefit of market access was found to be the most significant factor for both milk and meat producers. The market channel through the cooperative and the obligation to take all the milk produced saves transaction costs for dairy farmers, as they do not have to search for a buyer for the rest of the milk and continuously renegotiate contracts. This relates to the frequency of transactions and perishability of the production. The observed higher significance of the cooperative market channel to large milk producers relative to smaller producers supports the hypothesis that cooperative membership provides protection for specific investments. Distance is in theory a factor that contributes to the level of transaction costs, but only tentative evidence was observed in this study. Proximity was valued by the members of small dairy marketing cooperatives, but this finding is more likely to be related to some sort of regional spirit and support for the local community than to transaction cost benefits. In dairy cooperatives, farmers are in fact indifferent to the distance factors, because the cooperative bears the transaction costs of collecting the milk from farms. In meat cooperatives, the delivery distance may be built into the pricing policy, and we would therefore expect distance effects in the meat producer sample. However, we were unable to identify a statistically significant distance effect in the multivariate analysis.

The results of this study indicate that in parallel with the evolution of organizational structures of agricultural producers, the mechanisms for membership remuneration also need to be developed. Although the primary rationale for farmers to organize into cooperatives is still the facilitation of market access, some other factors such as bargaining power and control benefits may be losing their significance in vertically integrated hybrid structures. Satisfaction with the producer price level seems to be reflected in the overall satisfaction with cooperative membership. The findings of this study have managerial implications with respect to understanding the member perspectives. The observations emphasize the importance of the various forms of benefits, which have relatively different importance to producers depending on their farm size. Carefully designed benefit policies that cater to the farmer valuations are likely to encourage investments in the farm business and breed commitment to delivering.

Drawing from a single questionnaire, the paper has obvious limitations. The results provide a useful reference for agricultural organizations in similar situations with a closely corresponding member structure to that of the sample of this study. However, the results cannot be generalized to farmer cooperatives that are in very different stage of organizational development than those studied in the Finnish context. In addition, the sectors under study, dairy and meat production, are marked by certain features, which may not characterize some other agricultural sectors, and thus the member benefits may be valued very differently by other type of farmers. Due to data limitations in a stated preference method of this study, the measuring of transaction costs is only an approximation at best. Further studies could aim at developing more accurate survey instruments and methods to measure transaction costs at farms and benefits from cooperative membership. 


\section{Appendix}

Table 7 Marginal effects of ordered probit estimation

\begin{tabular}{|c|c|c|c|c|c|}
\hline Variable & Very insignificant & Insignificant & Indifferent & Significant & Very significant \\
\hline \multicolumn{6}{|l|}{ (1) Market channel } \\
\hline Dairy dummy & -0.077 & -0.033 & -0.126 & -0.225 & 0.461 \\
\hline Pig dummy & -0.014 & -0.009 & -0.045 & -0.177 & 0.245 \\
\hline Buyers & -0.005 & -0.003 & -0.012 & -0.033 & 0.052 \\
\hline Expanded dummy & -0.011 & -0.006 & -0.030 & -0.093 & 0.140 \\
\hline Will expand dummy & -0.013 & -0.008 & -0.038 & -0.121 & 0.180 \\
\hline Marketing dummy & 0.023 & 0.012 & 0.049 & 0.102 & -0.185 \\
\hline Dairy-large dummy & -0.005 & -0.003 & -0.015 & -0.045 & 0.068 \\
\hline Pig-large dummy & 0.031 & 0.015 & 0.059 & 0.111 & -0.216 \\
\hline \multicolumn{6}{|l|}{ (2) Proximity } \\
\hline Dairy dummy & -0.066 & -0.053 & -0.123 & -0.212 & 0.453 \\
\hline Pig dummy & -0.010 & -0.012 & -0.040 & -0.136 & 0.198 \\
\hline Buyers & -0.001 & -0.001 & -0.004 & -0.010 & 0.017 \\
\hline Expanded dummy & -0.006 & -0.007 & -0.021 & -0.059 & 0.093 \\
\hline Will expand dummy & -0.009 & -0.010 & -0.031 & -0.087 & 0.137 \\
\hline Marketing dummy & 0.025 & 0.023 & 0.057 & 0.108 & -0.212 \\
\hline Dairy-large dummy & -0.004 & -0.004 & -0.013 & -0.036 & 0.057 \\
\hline Pig-large dummy & 0.003 & 0.003 & 0.009 & 0.022 & -0.037 \\
\hline \multicolumn{6}{|l|}{ (3) Services } \\
\hline Dairy dummy & -0.122 & -0.206 & -0.242 & 0.265 & 0.305 \\
\hline Pig dummy & -0.010 & -0.036 & -0.099 & 0.017 & 0.127 \\
\hline Buyers & -0.003 & -0.009 & -0.020 & 0.010 & 0.022 \\
\hline Expanded dummy & -0.007 & -0.022 & -0.052 & 0.021 & 0.059 \\
\hline Will expand dummy & -0.017 & -0.058 & -0.154 & 0.031 & 0.198 \\
\hline Marketing dummy & 0.006 & 0.016 & 0.034 & -0.020 & -0.036 \\
\hline Dairy-large dummy & 0.012 & 0.035 & 0.068 & -0.043 & -0.071 \\
\hline Pig-large dummy & 0.075 & 0.135 & 0.143 & -0.205 & -0.148 \\
\hline \multicolumn{6}{|l|}{ (4) Producer price } \\
\hline Dairy dummy & -0.061 & -0.066 & -0.162 & -0.128 & 0.417 \\
\hline Pig dummy & -0.009 & -0.015 & -0.053 & -0.080 & 0.157 \\
\hline Buyers & -0.007 & -0.010 & -0.032 & -0.038 & 0.088 \\
\hline Expanded dummy & -0.013 & -0.020 & -0.066 & -0.091 & 0.190 \\
\hline Will expand dummy & -0.012 & -0.018 & -0.062 & -0.085 & 0.178 \\
\hline Marketing dummy & 0.027 & 0.032 & 0.084 & 0.069 & -0.213 \\
\hline Dairy-large dummy & -0.002 & -0.004 & -0.011 & -0.014 & 0.031 \\
\hline Pig-large dummy & 0.184 & 0.122 & 0.189 & 0.008 & -0.503 \\
\hline \multicolumn{6}{|l|}{ (5) Bargaining power } \\
\hline Dairy dummy & -0.083 & -0.139 & -0.174 & 0.119 & 0.277 \\
\hline Pig dummy & -0.017 & -0.047 & -0.109 & -0.005 & 0.178 \\
\hline Buyers & -0.007 & -0.017 & -0.030 & 0.009 & 0.045 \\
\hline Expanded dummy & -0.017 & -0.042 & -0.086 & 0.013 & 0.132 \\
\hline Will expand dummy & -0.021 & -0.054 & -0.112 & 0.011 & 0.176 \\
\hline
\end{tabular}


Table 7 Marginal effects of ordered probit estimation (Continued)

\begin{tabular}{lrrrrr}
\hline Marketing dummy & 0.032 & 0.062 & 0.084 & -0.054 & -0.123 \\
Dairy-large dummy & 0.013 & 0.029 & 0.047 & -0.020 & -0.069 \\
Pig-large dummy & 0.206 & 0.196 & 0.084 & -0.249 & -0.237 \\
(6) Control & & & & & \\
Dairy dummy & -0.056 & -0.070 & -0.019 & 0.077 & 0.066 \\
Pig dummy & -0.048 & -0.085 & -0.064 & 0.079 & 0.118 \\
Buyers & -0.011 & -0.016 & -0.006 & 0.017 & 0.017 \\
Expanded dummy & -0.035 & -0.053 & -0.027 & 0.055 & 0.060 \\
Will expand dummy & -0.028 & -0.042 & -0.021 & 0.044 & 0.047 \\
Marketing dummy & 0.040 & 0.049 & 0.010 & -0.055 & -0.044 \\
Dairy-large dummy & 0.010 & 0.014 & 0.005 & -0.015 & -0.014 \\
Pig-large dummy & 0.235 & 0.141 & -0.075 & -0.197 & -0.104 \\
\hline
\end{tabular}

\section{Competing interests}

The author declares that he/she has no competing interests.

Received: 20 January 2015 Accepted: 14 September 2015

Published online: 22 September 2015

\section{References}

Alsemgeest L, Smit A (2012) Wearing two hats - the conflict between being an agricultural business customer and shareholder. J Co-op Stu 45(3):5-16

Bijman J, Iliopoulos C, Poppe K, Gijselinckx C, Hagedorn K, Hanisch M, Hendrikse G, Kühl R, Ollila P, Pyykkönen P, van der Sangen G (2012) Support for farmers' cooperatives; Final report. November 2012. Wageningen UR, Wageningen, Netherlands

Chaddad F, Cook M (2004) Understanding new cooperative models: An ownership-control rights typology. Rev of Agric Econ 26(3):348-360

Chaddad F, lliopoulos C (2013) Control rights, governance, and the costs of ownership in agricultural cooperatives. Agribusiness 29(1):3-22

Chechin A, Bijman J, Pascucci S, Omta O (2013) Decomposing the member relationship in agricultural cooperatives: Implications for commitment. Agribusiness 29(1):39-61

Daykin A, Moffatt P (2002) Analyzing ordered responses: A review of the ordered probit model. Understanding Statistics 1(3):157-166

de Winter J, Dodou D (2010) Five-point Likert items: $t$ test versus Mann-Whitney-Wilcoxon. Practical Assess Res Eval 15:11

Greene W (2000) Econometric analysis. 4th edition Pearson-Prentice Hall

Hansmann H (1988) Ownership of the firm. J Law Econ and Org 4(2):267-304

Hendrikse G, Bijman J (2002) Ownership structure in agrifood chains: The marketing cooperative. Am J Agric Econ 84:104-119

Hernández-Espallardo M, Arcas-Lario N, Marcos-Matás G (2013) Farmers' satisfaction and intention to continue membership in agricultural marketing co-operatives: neoclassical versus transaction cost considerations. Eur Rev Agric Econ 40(2):23-260

KAKS, Kunnallisalan kehittämissäätiö (2004) Sosiaalinen pääoma Suomen kunnissa. Kunnallisalan kehittämissäätiön tutkimusjulkaisut nro 42

Masten S (2000) Transaction-cost economics and the organization of agricultural transactions. In: MRBaye (ed) Advances in Applied Microeconomics - Industrial Organization., pp 173-195

Ménard C (2004) The economics of hybrid organizations. J Inst Theor Econ 160:345-376

Niemi J, Ahlstedt A (eds) (2013) Finnish agriculture and rural industries 2013. MTT Agrifood Research Finland Publications, Finland, p 144a

Nilsson J, Kihlén A, Norell L (2009) Are traditional cooperatives an endangered species? About shrinking satisfaction, involvement and trust. Int Food and Agrib Man Rev 12:101-122

Pascucci S, Gardebroek C, Dries L (2012) Some like to join, some like to deliver: an econometric analysis of farmers' relationships with agricultural cooperatives. Eur Rev Agric Econ 39(1):51-74

Pyykkönen P, Bäckman S, Ollila P (2012) Support for farmers' cooperatives; Sector report pig meat. November 2012. Wageningen UR, Wageningen, Netherlands

Staatz J (1987) Farmers' incentives to take collective action via cooperatives: a transaction cost approach. In: Royer JS (ed) Cooperative Theory, New Approaches. USDA, Washington, pp 87-107, ACS Report No. 18

Sykuta M, Cook M (2001) Cooperative and membership commitment: A new institutional economics approach to contracts and cooperatives. Am J Agric Econ 83:1273-1279

Valentinov V (2007) Why are cooperatives important in agriculture? An organizational economics perspective. J Inst Econ 3(1):55-69

van Bekkum O, Bijman J (2006) Innovations in cooperative ownership: Converted and hybrid listed cooperatives. Business paper presented at the 7th International Conference on Management in Agrifood Chains and Networks, Ede

Williamson O (1989) Transaction Cost Economics. In: Handbook of Industrial Organization I., pp 136-159 